\title{
A comparison of the effectiveness of rosuvastatin, atorvastatin and simvastatin in achieving target lipid levels (according to the PROFILE-I registry)
}

\author{
Gaisenok O.V. ${ }^{1,2,3}$ \\ ${ }^{1}$ FSIUnited Hospital with Outpatient department,Moscow, \\ Russia \\ ${ }^{2}$ Research Center of Medical forecasting and analysis, \\ Moscow, Russia \\ ${ }^{3}$ National Research Center of preventive medicine, \\ Moscow, Russia
}

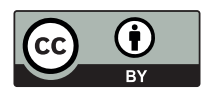

International License

Received: 28.10.17

Accepted: 13.12 .17

UDC: 616.1

\section{J Clin Med Kaz 2017;4(46):20-25}

Corresponding author: Gaisenok O.V. Address for correspondence: Russia, 119285, Moscow, Michurinsky Avenue, 6. FSI United Hospital with Outpatient department, e-mail: ovg.07@bk.ru
Abstract

The aim of the study: was to evaluate the effectiveness of lipid-lowering therapy, depending on the choice of statin in patients with cardiovascular disease in a cohort study.

Methods: Data analysis was performed in the Profile-I registry patients. The results of the examination of 148 patients were selected for the final analysis on the basis of the presence of indications for prescribing statins, the availability of data on the choice of statin and the availability of results of lipid spectrum from 274 registry patients.

Results: The values of total cholesterol and LDL-C were significantly lower in the rosuvastatin group than in the atorvastatin and simvastatin groups (respectively 4.3, 4.7 and $4.6 \mathrm{mmol} / \mathrm{l}, \mathrm{p}=0.03 ; 2.36,2.98$, and $2.66 \mathrm{mmol} / \mathrm{l}, \mathrm{p}$ $=0.01)$.

Conclusion: the achievement of more optimal levels of lipid spectrum turned out to be dependent on the choice of statin in this study in favor of rosuvastatin.

Key words: target lipid levels, lipid-lowering therapy, rosuvastatin, atorvastatin, simvastatin

ТӨМЕНГІ ТЫҒЫЗДЫЛЫҚТЫ ЖАЛПЫ ХОЛЕСТЕРИН МЕН ЛИПОПРОТЕИДТЕРДІН МАҚСАТТЫ ДЕНГЕЙЛЕРІНЕ ҚОЛЖЕТКІЗУДЕ РОЗУВАСТАТИНДІ, АТОРВАСТАТИН МЕН СИМВАСТАТИНДІ ҚОЛДАНУ ТИІМДІЛІГІН САЛЫСТЫРУ (ТІРКЕЛІМНІН ДЕРЕКТЕРІ БОЙЫНША БЕЙІНІ І)

Гайсёнок О.В. ${ }^{1,2,3}$

${ }^{1}$ РФПІБ емханасымен біріктірілген ФМБМ ауруханасы,

${ }^{2}$ Медициналық болжау және талдаудың зерттеу орталығы,

${ }^{3}$ Ұлттық зерттеу профилактикалық медицина орталығы, Мәскеу, Ресей

\section{ТҰЖЫРЫМДАМА}

Зерттеу мақсаты: шоғырламалық әдісте жүрек-тамырлы аурулары бар пациенттерде статинді іріктеуге байланысты жүргізіліп жатқан гиполипидемиялық терапияның тиімділігін бағалау.

Әдістері: деректерді талдау Бейін-І тіркелімінің пациенттеріне жүргізілді. Тіркелімнің 274 пациентінен статиндерді жазып беруге көрсеткіштерді ескерумен, препаратты таңдау бойынша деректердің болуы және түпкілікті талдау үшін липид спектрін зерттеу нәтижелерінің болуы 148 пациенттен зерттеу нәтижелері іріктелді.

Нәтижелері: ТТЛП және ОХС көрсеткіштері аторвастатин мен симвастатин топтарымен салыстырғанда (тиісінше 4,3, 4,7 және 4,6 ммоль/л, $p=0,03 ; 2,36,2,98$ және 2,66 ммоль/л, $p=0,01$ )

Тұжырымдар: липидті спектр көрсеткіштерінің аса оңтайлы деңгейлеріне қолжеткізу розувастатиннің пайдасында осы зерттеуде стантинді таңдауға тәуелді болды.

Түйінді сөздер: липидтердің мақсатты деңгейлері, гиполипидемиялық терапия, розувастатин, аторвастатин, симвастатин. 
СРАВНЕНИЕ ЭФФЕКТИВНОСТИ ПРИМЕНЕНИЯ РОЗУВАСТАТИНА, АТОРВАСТАТИНА И СИМВАСТАТИНА В ДОСТИЖЕНИИ ЦЕЛЕВЫХ УРОВНЕЙ ОБЩЕГО ХОЛЕСТЕРИНА И ЛИПОПРОТЕИДОВ НИЗКОЙ ПЛОТНОСТИ (ПО ДАННЫМ РЕГИСТРА ПРОФИЛЬ-І)

Гайсёнок О.В. ${ }^{1,2,3}$

${ }^{1}$ ФБУ Объединенная больница с поликлиникой УдПРФ,

${ }^{2}$ Исследовательский центр медицинского прогнозирования и анализа,

${ }^{3}$ Национальный исследовательский центр профилактической медицины, Москва, Россия

\section{РЕЗЮМЕ}

Цель исследования: оценить эффрективность проводимой гиполипидемической терапии в зависимости от выбора статина у пациентов с сердечно-сосудистыми заболеваниями в когортном исследовании.

Методы: анализ данных проводился у пациентов регистра Профиль-І. Из 274 пациентов регистра с учетом наличия показаний для назначения статинов, наличия данных по выбору препарата и наличия результатов исследования липидного спектра для окончательного анализа были отобраны результаты исследования 148 пациентов.

Результаты: показатели ОХС и ЛПНП были зарегистрированызначимо ниже в группе розувастатина, в сравнении с группами аторвастатина и симвастатина (соответственно 4,3, 4,7 и 4,6 ммоль/л, p=0,03; 2,36, 2,98 и 2,66 ммоль/л, p=0,01).

Выводы: достижение более оптимальных уровней показателей липидного спектра оказалось зависимым от выбора статина в данном исследовании в пользу розувастатина.

Ключевые слова: целевые уровни липидов, гиполипидемическая терапия, розувастатин, аторвастатин, симвастатин

\section{Introduction}

The need to use statins to achieve the target levels of total cholesterol (TC), LDL-C, HDL-C and triglycerides (TG) is emphasized in international recommendations [1]. The relationship between the level of LDL and the frequency of cardiovascular complications has been proved in large studies [2-7]. Despite the existing recommendations, Russian realities have always differed from the situation in Western Europe and the United States. Thus, the following results were obtained in the Moscow statins study: only $30 \%$ of patients with IHD received statins; $80 \%$ of the appointments were simvastatin and lovastatin in the initial doses; the average duration of treatment was 5 months [8]. The first generation of statins (pravastatin, lovastatin) gave way to subsequent generations. Currently, in clinical practice, it is almost impossible to meet patients who take them. The most prescribed are well-proven simvastatin, atorvastatin and rosuvastatin. The role of the latter one in influencing the regression of atherosclerosis, cardiovascular and general mortality was devoted to large-scale international studies [9-12]. However, it should be noted that most studies of rosuvastatin were devoted to primary prevention of cardiovascular diseases; at the same time as atorvastatin has the greatest evidence base for secondary prevention [9,13-16].

The aim of the study:

to evaluate the effectiveness of lipid-lowering therapy, depending on the choice of statin in patients with cardiovascular disease in a cohort study.

\section{Materials and methods}

The data of the registry of the Department of Preventive Pharmacotherapy of the National Research Center of preventive medicine of the Ministry of Health of the Russian Federation (NRCPM) were conducted for the present study. Patients who applied to the department for the purpose of consulting about cardiovascular diseases were consistently included in this registry (Profile registry). The registration card developed by the researchers was filled out for each patient who appealed based on the results of the examination and the standard survey. Specially developed for this study questionnaire, which allows to assess the patient's attitude to the problem of atherosclerosis, compliance with the hypocholesterolemic diet, drugs prescribed for correction of lipid metabolism disorders, regularity of their intake, reasons for refusing treatment, etc., was also given to each patient. The registration card was filled in by the doctor, and the questionnaire was filled in by the patient. All patients signed informed consent to participate in the study, and the questionnaire was approved by the Independent Ethics Committee of the Institute. Blood tests for the content of cholesterol and its fractions were conducted in the laboratory of NRCPM directly on the day of appeal of the patient.

Data analysis was performed in 274 patients. All patients were divided into 2 groups: main and control. Patients who had not previously been observed and did not apply to the NRCPM were included in the control group $(\mathrm{CG}, \mathrm{n}=82)$. Patients who had previously visited the NRCPM or were observed in the NRCPM for a long time entered in the main group ( $M G, n=192)$. The main group was divided into 2 subgroups: main group A (MG$A, n=167$ ), whose last visit, according to the registry data, took place less than 2 years ago, and the main group B (MG-B, $\mathrm{n}=$ 25), whose last visit to the NRCPM took place more than 2 years ago. The distribution of patients in the groups for taking statins was as follows: CG - 25 patients, MG-A - 112 patients, MG-B - 12 patients. The following data were analyzed: indications for prescribing statins, availability of data on the choice of the drug, availability of results of lipid spectrum research. Based on this, the results of a study of 148 patients were possible for the final data analysis.

After evaluating the representativeness of the sample for the received statins, the lovastatin group was excluded from the subsequent analysis due to their small number $(\mathrm{n}=1)$.

\section{Statistical analysis}

Statistical data processing was carried out using the software package Statistica 6.0 (Statsoft). The data for the groups are presented in the form of a median and interquartile range. Rank-based analysis of Kruskal-Wallis variations was applied for multiple comparison of groups by a quantitative sign. The $\chi 2$ criterion was used to compare the groups by the qualitative sign. Rank correlation analysis by Spearman was used to assess the existence of a relationship between quantitative and qualitative ordinal signs. Differences were considered statistically significant at $\mathrm{p}<0.05$.

\section{Results}

The baseline clinical characteristics of the patients are shown in Table 1. 


\begin{tabular}{|l|l|}
\hline Age, year [IQR] & $64.0[57.0 ; 72.0]$ \\
\hline Female, $\mathrm{n}(\%)$ & $139(50.7 \%)$ \\
\hline Body mass index, $\mathrm{kg} / \mathrm{m} 2[\mathrm{IQR}]$ & $28.7[25.4 ; 31.3]$ \\
\hline Hypercholesterolemia at baseline $5.0, \mathrm{mmol} / \mathrm{l}(\%)$ & $266(97.0 \%)$ \\
\hline Hypercholesterolemia in the present time> 5.0, mmol/l (\%) & $113(41.2 \%)$ \\
\hline Hypercholesterolemia in the present time> 4.5, mmol/l $(\%)$ & $153(55.8 \%)$ \\
\hline Hypertension, $\mathrm{n}(\%)$ & $230(83.9 \%)$ \\
\hline Coronary artery disease, $\mathrm{n}(\%)$ & $85(31.0 \%)$ \\
\hline History of myocardial infarction, $\mathrm{n}(\%)$ & $47(17.1 \%)$ \\
\hline Diabetes mellitus, $\mathrm{n}(\%)$ & $43(15.7 \%)$ \\
\hline History of stroke, $\mathrm{n}(\%)$ & $19(6.9 \%)$ \\
\hline
\end{tabular}

Spearman rank correlation analysis noted a positive correlation between the increase in the dose of statin with BMI $(\mathrm{R}=0.18, \mathrm{p}=0.03)$ and with the level of creatine phosphokinase (CPK) $(\mathrm{R}=0.32, \mathrm{p}=0.009)$.

Achievement of optimal levels of lipid spectrum turned out to be dependent on the choice of statin for the whole cohort of the study. The values of total cholesterol and LDL were significantly lower in the rosuvastatin group, in comparison with atorvastatin and simvastatin groups. At the same time, there was registered a higher level of aspartate aminotransferase (AST) in this group (Table 2, Fig.1-3).

Table 2 Comparative characteristics of groups depending on the choice of statin on the basic laboratory parameters.

\begin{tabular}{|l|l|l|l|l|}
\hline & Atorvastatin (n=38) & Rosuvastatin (n=50) & Simvastatin (n=57) & P-level \\
\hline TC, mmol/l & $4,70[4,00-5,28]$ & $4,30[3,65-4,80]$ & $4,60[4,00-5,40]$ & 0.037 \\
\hline LDL, mmol/l & $2,98[2,34-3,62]$ & $2,36[3,65-4,8]$ & $2,66[2,03-3,43]$ & 0,017 \\
\hline VLDL, $\mathrm{mmol} / \mathrm{l}$ & $0,54[0,44-0,64]$ & $0,57[0,41-0,73]$ & $0,70[0,53-0,93]$ & 0,072 \\
\hline HDL, $\mathrm{mmol} / \mathrm{l}$ & $1,13[1,01-1,33]$ & $1,22[1,06-1,36]$ & $1,19[1,03-1,47]$ & 0,591 \\
\hline TG, $\mathrm{mmol} / \mathrm{l}$ & $1,27[0,97-1,62]$ & $1,16[0,87-1,70]$ & $1,31[0,89-2,06]$ & 0,579 \\
\hline AST, u/l & $25,00[21,50-28,50]$ & $25,00[22,00-38,00]$ & $22,00[17,50-25,20]$ & 0,022 \\
\hline ALT u/l & $26,00[22,00-35,00]$ & $27,00[22,00-44,00]$ & $22,85[15,50-36,00]$ & 0,147 \\
\hline CPK, u/l & $131,50[104,00-180,00]$ & $95,00[78,00-163,00]$ & $130,00[96,00-194,00]$ & 0,231 \\
\hline Bilirubin, mkmol/l & $12,00[8,00-15,40]$ & $11,00[9,00-19,00]$ & $11,00[10,00-16,00]$ & 0,596 \\
\hline
\end{tabular}

Data presented as median and [IQR].

Abbreviations: TC - total cholesterol; LDL - low density lipoproteins; VLDL - very low density lipoproteins; TG - triglycerides;

AST - aspartate aminotransferase; ALT - aspartate aminotransferase; CPK - creatine phosphokinase

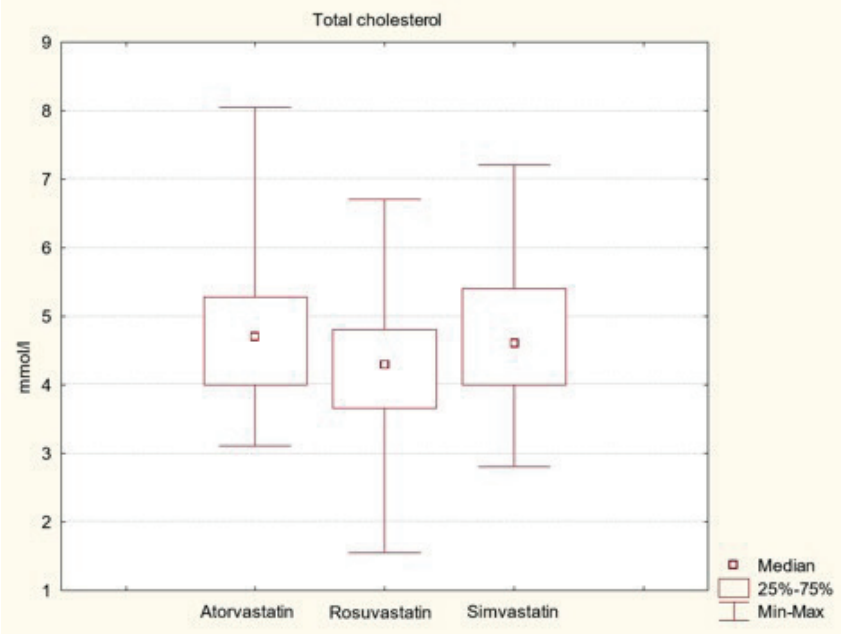

Figure 1 - Group differences in the level of total cholesterol depending on the choice of statin.

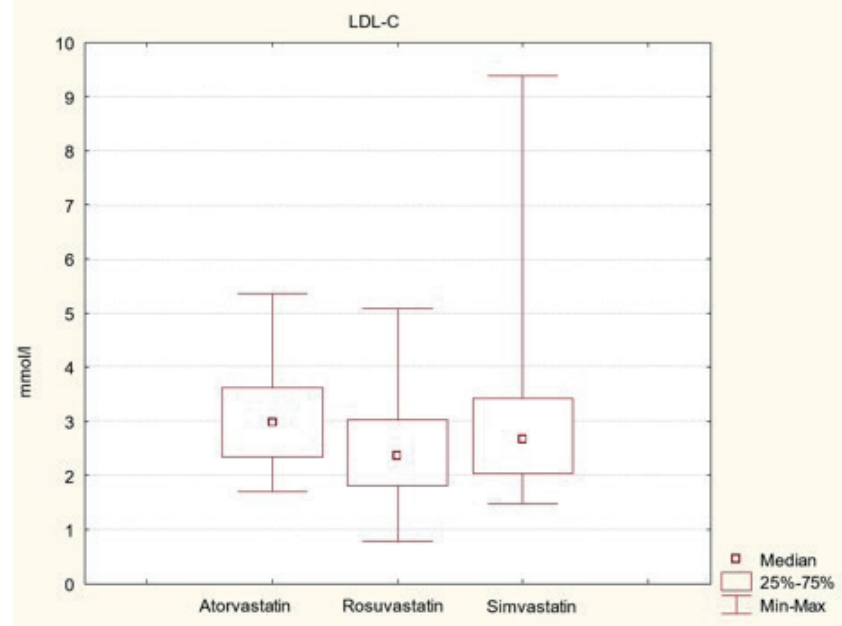

Figure 2 - Group differences in the level of LDL-C depending on the choice of statin. 


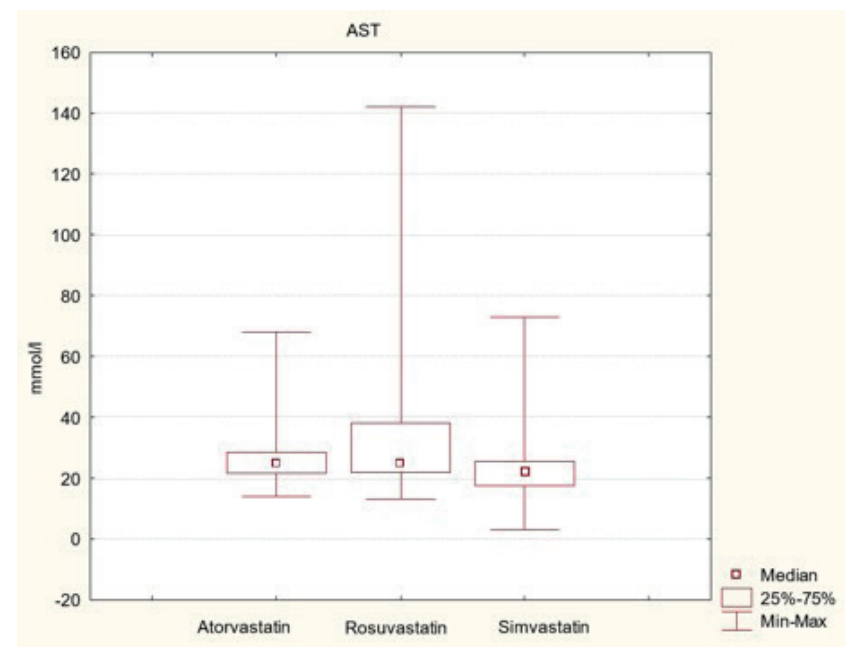

Figure 3 - Group differences in the level of aspartate transferase (AST) depending on the choice of statin

The most commonly prescribed statins in the analysis of the data obtained in the study group were Crestor and Zocor (see Table 3).

Table 3 Patient distribution $(\mathrm{n}=145)$, depending on the choice of the particular drug (statin).

\begin{tabular}{|l|l|l|l|}
\hline Active substance & Name of the drug & Number of patients & $\%$ of the total \\
\hline Atorvastatin & & & \\
\hline & Liprimar & 17 & $11,7 \%$ \\
\hline & Torvacard & 13 & $8,9 \%$ \\
\hline & Atorvastatin & 5 & $3,4 \%$ \\
\hline & Atoris & 2 & $1,3 \%$ \\
\hline & Tulip & 1 & $0,7 \%$ \\
\hline Simvastatin & & & \\
\hline & Zocor & 29 & $20,0 \%$ \\
\hline & Simgal & 18 & $12,4 \%$ \\
\hline & Simvastatin & 5 & $3,4 \%$ \\
\hline & Simvastol & 2 & $1,3 \%$ \\
\hline & Vazilip & 2 & $1,3 \%$ \\
\hline & Simvacard & 1 & $0,7 \%$ \\
\hline Rosuvastatin & Crestor & 49 & $33,8 \%$ \\
\hline & Mertinil & 1 & $0,7 \%$ \\
\hline & & &
\end{tabular}

Data analysis of the choice of statin depending on primary or secondary prophylaxis (the presence of IHD) for the whole cohort of the study (see Table 4) showed no statistically significant differences: $\chi 2=3.053, \mathrm{df}=2, \mathrm{p}=0.217$. Also statistically significant differences were not found in a separate analysis for CG, MG-A and MG-B groups.

Table 4 Statin prescriptions depending on primary or secondary prophylaxis (presence of IHD) for the entire study cohort $(n=142)$

\begin{tabular}{|l|l|l|}
\hline Type of statin & Presence of IHD & Absence of IHD \\
\hline Rosuvastatin, $\mathrm{n}(\%)$ & $25(\%)$ & $25(\%)$ \\
\hline Atorvastatin, $\mathrm{n}(\%)$ & $23(\%)$ & $14(\%)$ \\
\hline Simvastatin, $\mathrm{n}(\%)$ & $24(\%)$ & $31(\%)$ \\
\hline
\end{tabular}

The achievement of target lipid levels in the analysis of the data obtained among all categories was as follows (presented as a median for TC and LDL): 1st group (CG) - target levels for atorvastatin were not achieved for both primary and secondary prevention; the target levels for rosuvastatin $(3.7,1.81)$ and simvastatin $(3.95,1.84)$ were achieved only for primary prevention (without IHD);2nd group (MG-A) - target levels for atorvastatin and simvastatin were not achieved for both primary and secondary prevention; target levels were achieved for rosuvastatin for both primary $(4.66,2.72)$ and for secondary prevention (3.8, 2.19);3rd group (MG-B) - target levels for atorvastatin were not achieved for both primary and secondary prevention; the target levels for rosuvastatin were achieved for all categories - for patients with $\operatorname{IHD}(3.1,1.41)$ and for patients without IHD $(4.6,2.65)$; for simvastatin - only for patients without IHD (4.0, 1.92).

\section{Discussion}

The problem of insufficient effectiveness of lipid-lowering therapy is still relevant, including for developed countries. Therapeutic goals do not achieve the desired result in many patients. So out of 4407 patients with dyslipidemia included in the EURIKA study, 74\% received lipid-lowering medications, but only $43 \%$ of treated patients achieved a total cholesterol target of $<5 \mathrm{mmol} / 1$ [17].

In this aspect, the search for a more effective drug and its optimal dose was an active issue for scientists of different countries. In earlier studies, attempts have been made to compare the effectiveness of the currently used statins (atorvastatin, rosuvastatin and simvastatin) [18-20]. In the above statin studies, the benefits were on the side of rosuvastatin. In this aspect, it is probably worth discussing the pleiotropic effects of statins, namely their anti-inflammatory properties, which have been proven to be the most effective for rosuvastatin [12,21-23].

At the same time would like to cite the results of a randomized study devoted to this problem. The Measuring Effective Reductions in Cholesterol Using Rosuvastatin Therapy I (MERCURY I) trial compared rosuvastatin $10 \mathrm{mg}$ with atorvastatin $10 \mathrm{mg}$ and $20 \mathrm{mg}$, simvastatin $20 \mathrm{mg}$ and pravastatin $40 \mathrm{mg}$ over 8 weeks in patients with coronary or other atherosclerotic diseases or diabetes who had fasting levels of LDL-C of $>$ or $=2.99 \mathrm{mmol} / 1$ and triglycerides of $<4.52$ mmol/1. Modified National Cholesterol Education Program Adult Treatment Panel III (ATP III) criteria for the metabolic syndrome were met by 1342 (43\%) of 3140 patients. The main results of this study showed that treatment with rosuvastatin 10 mg was more effective in allowing patients with and without the metabolic syndrome to reach European and ATP III LDL-C goals, compared to atorvastatin $10 \mathrm{mg}$, simvastatin $20 \mathrm{mg}$ and pravastatin $40 \mathrm{mg}$ ( $\mathrm{p}<0.0001$ for all comparisons); consistently produced greater reductions in LDL-C, total cholesterol and nonHDL-C, compared to these treatments; and produced similar or greater reductions in triglycerides and increases in HDL-C, compared to the other treatments [24].

According to our study, we can conclude that the most frequently prescribed statins were the original drugs of rosuvastatin and simvastatin. Rosuvastatin was more often prescribed to patients with an established diagnosis of IHD, which in a sense contradicts the current evidence base. Since most rosuvastatin studies concerned to primary prevention. Probably, this was due to the doctors' desire to quickly achieve the target levels of total cholesterol and LDL-C, as the simplicity and effectiveness of the initial dose of rosuvastatin $10 \mathrm{mg}$ did not require its titration in most cases. Unlike rosuvastatin, atorvastatin and simvastatin required more regular monitoring of blood tests for lipid spectrum.

It is known that equivalent doses of rosuvastatin $10 \mathrm{mg}$ are $20 \mathrm{mg}$ of atorvastatin and $40 \mathrm{mg}$ of simvastatin [25]. In 
this regard, to assess the comparability of doses of prescribed drugs, an analysis was performed in the cohort of the study, on the basis of which all patients were divided according to the administration of statin to a low, medium and high dose of the drug (see Table 5).

Table 5 Distribution according to the doses of the statin taking into account the comparability of the doses of drugs $(n=142)$

\begin{tabular}{|c|c|c|c|}
\hline Dose of the drug & Rosuvastatin & Atorvastatin & Simvastatin \\
\hline \multirow[t]{2}{*}{ Low } & $\begin{array}{l}\text { Rosuvastatin } \\
<10 \mathrm{M} \Gamma\end{array}$ & $\begin{array}{l}\text { Atorvastatin < } \\
20 \mathrm{Mг}\end{array}$ & $\begin{array}{l}\text { Simvastatin < } \\
40 \mathrm{M} \Gamma\end{array}$ \\
\hline & 0 & 11 & 48 \\
\hline \multirow[t]{2}{*}{ Medium } & $\begin{array}{l}\text { Rosuvastatin = } \\
10 \mathrm{M \Gamma}\end{array}$ & $\begin{array}{l}\text { Atorvastatin = } \\
20 \mathrm{M \Gamma}\end{array}$ & $\begin{array}{l}\text { Simvastatin = } \\
40 \mathrm{M} \Gamma\end{array}$ \\
\hline & 37 & 19 & 7 \\
\hline \multirow[t]{2}{*}{ High } & $\begin{array}{l}\text { Rosuvastatin } \\
>10 \mathrm{мг}\end{array}$ & $\begin{array}{l}\text { Atorvastatin > } \\
20 \mathrm{Mг}\end{array}$ & $\begin{array}{l}\text { Simvastatin > } \\
40 \mathrm{M} \Gamma\end{array}$ \\
\hline & 13 & 7 & 0 \\
\hline
\end{tabular}

\section{References}

1. ESC/EAS Guidelines for the management of dyslipidaemias. The Task Force for the management of dyslipidaemias of the European Society of Cardiology (ESC) and the European Atherosclerosis Society (EAS). European Heart Journal (2011) 32, $1769-1818$

2. Long Term Intervention with Pravastatin in Ischaemic Disease (LIPID) Study Group. Prevention of cardiovascular events and death with pravastatin in patients with coronary heart disease and broad range of initial cholesterol levels. N Eng J Med. 1998; 339: 1349-57.

3. Plehn JF, Davis BR, Sacks FM, et al. Reduction of stroke incidence after myocardial infarction with pravastatin: the cholesterol and recurrent events (CARE) study. Circulation. 1999; 99: 216-23.

4. Heart Protection Study Collaborative Group. MRC/BHF Heart Protection Study of cholesterol lowering with simvastatin in 20,536 high-risk individuals: a randomised placebo-controlled trial. Lancet. 2002 Jul 6;360(9326):7-22.

5. West of Scotland Coronary Prevention Group. West of Scotland Coronary Prevention Study: identification of high risk groups and comparison with other cardiovascular intervention trials. Lancet. 1996; 348: 1339-42.

6. Downs JR, Clearfield M, Weis S, et al. for the AFCAPS/TexCAPS Research Group. Primary prevention of acute coronary events with lovastatin in men and women with average cholesterol levels. JAMA. 1998; 279:1615-1622.

7. Sever PS, Dahlof B, Poulter NR, et al. Prevention of coronary and stroke events with atorvastatin in hypertensive patients who have average or lower-than-average cholesterol concentrations, in the Anglo-Scandinavian cardiac Outcomes Trial-Lipid Lowering Arm (ASCOT-LLA): A multicentre randomized controlled trial. Lancet. 2003; 361: 1149-1158.

8. Susekov AV, ZubarevaM.Yu., Deev AD, et al. The main results of the Moscow Statin Survey (MSS). Serdtse. 2006; 6: 324-328 [In Russ].

9. Nissen SE, Tuzcu EM, Schoenhagen P, et al. (REVERSAL Investigators). Effect of intensive compared with moderate lipidlowering therapy on progression of coronary atherosclerosis: a randomized controlled trial. JAMA 2004; 9 (291): 1071-80.

10. Nissen SE, Nicholls SJ, Sipahy I, et al. Effect of very high-intensity statin therapy on regression of coronary atherosclerosis. The ASTEROID trial. JAMA 2006; 295 (13): 1556-65.

11. Crouse JR III, Raichlen JS, Riley WA. Effect of Rosuvastatin on Progression of Carotid Intima-Media Thickness in Low-Risk Individuals With Subclinical Atherosclerosis The METEOR Trial. JAMA 2007; 297: 1344-53.

12. Ridker PM, Danielson E, Fonseca FAH, et al. Reduction in C-reactive protein and LDL cholesterol and cardiovascular event rates after initiation of rosuvastatin: a prospective study of the JUPITER trial. Lancet. April 4, 2009; 373: 1175-82.

13. Waters D. Comparison of Aggressive Lipid Lowering with Atorvastatin vs. Revascularization Treatments (AVERT) and Conventional Care for the Reduction of Ischemic Events in Patients with Stable Coronary Artery Disease. Cardiovasc Rev Rep. $21(1): 26-31,2000$

14. Schwartz GG, Olsson AG, Ezekowitz MD et al. Effects of atorvastatin on early recurrent ischemic events in acute coronary syndromes: the MIRACL study - a randomized controlled trial. JAMA 2001; 285: 1711-8.

15. Amarenco P, Bogousslavsky J, Amarenco P et al. High-dose atorvastatin after stroke or transient ischemic attack. N Engl J Med 2006; 355: 549-59.

16. The SPARCL Investigators. Design and baseline characteristics of the stroke prevention by aggressive reduction in cholesterol levels (SPARCL). Cerebrovasc Dis 2003; 16: 389-95.

17. Banegas JR, López-García E, Dallongeville J, Guallar E, Halcox JP, Borghi C, et al. Achievement of treatment goals for primary prevention of cardiovascular disease in clinical practice across Europe: the EURIKA study. Eur Heart J. 2011 Sep;32(17):214352. doi: 10.1093/eurheartj/ehr080. Epub 2011 Apr 6. 
18. Bener A, Dogan M, Barakat L, Al-Hamaq AO. Comparison of efficacy, safety, and cost-effectiveness of various statins in dyslipidemic diabetic patients. Indian J Pharmacol. 2014 Jan-Feb;46(1):88-93. doi: 10.4103/0253-7613.125184. PMID: 24550591 PMCID: PMC3912814

19. Tran YB, Frial T, Miller PS. Statin's cost-effectiveness: a Canadian analysis of commonly prescribed generic and brand name statins. Can J Clin Pharmacol. 2007 Summer;14(2):e205-14. Epub 2007 Jun 5. PMID: 17556788

20. Bener A, Dogan M, Barakat L, Al-Hamaq AO. Comparison of Cost-Effectiveness, Safety, and Efficacy of Rosuvastatin Versus Atorvastatin, Pravastatin, and Simvastatin in Dyslipidemic Diabetic Patients With or Without Metabolic Syndrome. J Prim Care Community Health. 2014 Jul;5(3):180-7. doi: 10.1177/2150131914520991. Epub 2014 Feb 11.

21. Mora S, Ridker PM. Justification for the Use of Statins in Primary Prevention: an Intervention Trial Evaluating Rosuvastatin (JUPITER)--can C-reactive protein be used to target statin therapy in primary prevention? Am J Cardiol. 2006 Jan 16;97(2A):33A41A. Epub 2005 Dec 1. Review. PMID: 16442935

22. McGuire TR, Kalil AC, Dobesh PP, Klepser DG, Olsen KM. Anti-inflammatory effects of rosuvastatin in healthy subjects: a prospective longitudinal study. Curr Pharm Des. 2014;20(7):1156-60. PMID: 24467235

23. Sexton TR, Wallace EL, Macaulay TE, Charnigo RJ, Evangelista V, Campbell CL, et al. The effect of rosuvastatin on thromboinflammation in the setting of acute coronary syndrome. J Thromb Thrombolysis. 2015 Feb;39(2):186-95. doi: 10.1007/ s11239-014-1142-x. PMID: 25307674

24. Stender S, Schuster H, Barter P, Watkins C, Kallend D; MERCURY I Study Group. Comparison of rosuvastatin with atorvastatin, simvastatin and pravastatin in achieving cholesterol goals and improving plasma lipids in hypercholesterolaemic patients with or without the metabolic syndrome in the MERCURY I trial. Diabetes Obes Metab. 2005 Jul;7(4):430-8. PMID: 15955130 DOI: 10.1111/j.1463-1326.2004.00450.x

25. Statins - HMG-CoA Reductase Inhibitors - Comparative properties / http://www.globalrph.com/statins_comparisons.htm

How to cite this article: Oleg V Gaisenok. A comparison of the effectiveness of rosuvastatin, atorvastatin and simvastatin in achieving target lipid levels (according to the PROFILE-I registry). J Clin Med Kaz. 2017;4(46):20-25. 